Z. Klin. Chem. Klin. Biochem.

12. Jg. 1974, S. 353-356

\title{
Comparative Investigation on the Activity of a Synthetic Corticotrophin (18-ACTH) A Clinical Trial
}

\author{
By P. J. Brombacher, Department of Clinical Chemistry
}

F. P. V. Maesen, Department of Pneumology

and A. H. J. Gijzen, Department of Clinical Chemistry

The DeWever-Ziekenhuis, Heerlen (L), The Netherlands

(Eingegangen am 7. Februar/11. April 1974)

\begin{abstract}
The effect of the administration of a synthetic peptide with corticotrophic properties (18-ACTH) on the plasma corticosteroid levels of 72 healthy volunteers was studied. The same effect is seen both after subcutaneous and intramuscular injection. Intravenous administration provokes a longer lasting influence on adrenocortical activity, especially when large doses of the peptide are given; side effects however plead against this method of stimulation of the adrenal cortex.

Discrepancies are reported between results from the fluorometric and radioimmuno assay of corticosteroids.
\end{abstract}

An 72 gesunden Probanden wurde der Einfluß der Applikation eines synthetischen Peptids mit Corticotropin-Eigenschaften (18-ACTH) auf die Corticosteroid-Konzentration im Plasma untersucht. Nach s.c.- und i.v.-Injektion wurde dieselbe Wirkung beobachtet. I.v.Applikation bedingt eine länger dauernde Wirkung auf die Nebennieren-Aktivität, besonders nach Gabe hoher Dosen des Peptids. Wegen der Nebenwirkungen ist diese Art der Stimulation jedoch nicht zu empfehlen.

Fluorimetrische Bestimmung der Corticosteroide und Radioimmunoassay ergaben unterschiedliche Werte.

The favourable effect of long term treatment of many diseases by corticosteroids is now generally recognized. An unwanted side effect of this therapy however is the continuous inhibition of the production of adrenocorticotrophin by the patient's hypophysis; this can eventually lead to hypotrophy or even atrophy of the adrenal cortex. In order to prevent this, corticosteroid therapy is often accompanied by parenteral administration of corticotrophin at regular intervals. In a number of cases (about $5 \%$ ) allergy was raised either against the animal (porcine) corticotrophin used or against accompanying protein impurities $(1,2,3)$. On account of this serious complication the risk of allergy had always to be balanced against the risk of adrenal cortex functional loss.

The situation was considerably improved when synthetic polypeptides with corticotrophic activity became available $(4,5)$, which can be regarded as far safer for use in human medicine; first because it is less likely that large molecules of foreign protein could be present as impurities and secondly because there is no difference in the sequence of the first 24 amino acids of ACTH in man and some animals $(6,7)$.

This synthetic $\beta^{1-24}$-corticotrophin appears to have acceptable corticotrophic activity although stimulation of the adrenal cortex is less than with ACTH of animal origin. Therapeutic use is now generally accepted (8).
In order to overcome the drawback of reduced activity, however, the synthesis of peptides with corticotrophic activity which are less biodegradable due to minor changes in the amino acid chain was investigated. These peptides should be long acting without the usual additives like zinc phosphate in the so called dêpot preparations $(9,10)$. An example is $D$-serine$L$-dilysine-17, $18-\beta^{1-18}$-corticotropinamide which we obtained for the clinical trial ${ }^{1}$ ) described here.

The effect of the administration of this substance to volunteers is reported in terms of plasma corticosteroid levels determined in two ways $(11,12)$.

\section{Purpose of the investigation}

With regard to experiments in animals (13) and reports on the clinical use of this so called 18-ACTH in a small number of patients (14) it can be expected that the substance will have good corticotrophic activity and will be long acting when administered to man.

A systematic investigation is performed with the help of 72 healthy volunteers. The mean body weight of the probands was $61.7 \mathrm{~kg}$, standard deviation $9.9 \mathrm{~kg}$.

\footnotetext{
1) Courtesy of CIBA-GEIGY Ltd.
} 
Their ages ranged from 18 to 46 years. No distinction was made between males and females. Neither of them took any drugs shortly before or during the trial.

Twelve blocks are formed by randomization. Six persons in one group all received the same treatment. The drug was administered either by subcutaneous injection or by intravenous injection or by intramuscular injection. The solvent used for the corticotrophins was $0.9 \%$ sodium chloride solution in water. The doses of $0.125 \mathrm{mg}, 0.25 \mathrm{mg}$ and $0.5 \mathrm{mg}$ were administered in $0.5 \mathrm{ml}$ solvent; the $1.0 \mathrm{mg}$ doses were administered in $1.0 \mathrm{ml}$ of solvent; those volumes were used for subcutaneous and intramuscular injections. Intravenous injections were given in $5 \mathrm{ml}$ of solvent slowly administered during two minutes in order to avoid unwanted reactions towards the injected peptide.

In each mode of administration four different doses were used $(0.125 \mathrm{mg}, 0.25 \mathrm{mg}, 0.50 \mathrm{mg}$ and $1.00 \mathrm{mg})$ to determine, if possible, the most suitable dose and method to obtain optimal stimulation of the human adrenal cortex when using the new drug.

\section{Materials and Methods}

The volunteers were hospitalized on the evening preceding the onset of the experiment. During the course of the trial they were strictly confined to their beds; no stress or smoking was allowed. The next morning a blood sample was taken at 8 a.m. whereupon the 18-ACTH was administered. More blood samples were taken after 2, 4, 8, 12, 24, and after intravenous administration also after 36 and 48 hours. The heparinised blood samples were taken to the laboratory at once where plasma was separated by centrifugation and frozen immediately in small portions at $-20^{\circ} \mathrm{C}$. Analysis was always performed within three days.

The corticotrophic effect of the administered preparation was measured on plasma corticosteroid levels. The amount of corticosteroids in each plasma sample was determined in two ways:

i) by measuring the fluorescence of the dichloromethane extract of plasma in ethanol/sulfuric acid according to the method described by Mattingly (11); excitation light $433 \mathrm{~nm}$ and emission wave length $539 \mathrm{~nm}$. Cortisol was used as a standard.

ii) by radioimmunoassay of the corticosteroids extracted from plasma by means of dichloromethane, using a described procedure (12) with the modification that instead of tritiated cortisol as a tracer we used cortisolsuccinyl: ${ }^{125}$ I-tyrosine methylester as a tracer on account of its $\gamma$-radiation. Again cortisol was taken as the standard.

In a number of samples total plasma ACTH was estimated in order to investigate possible correlation between values found for ACTH and plasma corticosteroids.

The estimation of ACTH was performed by radioimmunoassay (16) after extraction of corticotrophins from the plasma by means of porous glass beads (17). With the commercially available antibody (Radiochemical Centre, Amersham, Bucks., Great Britain) we used there was $90 \%$ cross reactivity towards purified human ACTH and 18-ACTH (to be publi- shed). The values found have thus to be regarded as representing the total amounts of endogenous and administered corticotrophins. Human ACTH (fraction 8B - Lerner and Upton) was used as a standard.

\section{Results}

Table 1 gives the results of corticosteroid analyses. (Standard deviations of the mean values are indicated at the bottom of the table.) Most elevated values are found after administration of the largest dose of 18-ACTH. As might be expected the fluorometric analysis gives values which are more elevated than those obtained by radioimmunoassay. There seems to be no appreciable difference between the effects of $0.25 \mathrm{mg}$ and $0.50 \mathrm{mg}$ of 18 -ACTH. It should be considered however that the corticotrophic effect cannot be fully evaluated by the maximal plasma cortisol level obtained. The duration of the stimulation should be taken into account as well. Therefore the overall effect is better measured by calculating the surface under the curve in the graphical presentation of plasma corticisteroid values versus time. Those calculated values are given in table 2 . Once more there appears to be not much difference between the effects of $0.25 \mathrm{mg}$ and $0.50 \mathrm{mg}$ of 18-ACTH. There are no striking differences between the effects of subcutaneous or intramuscular administration, which is in accordance with our own previous experience with other corticotrophic. peptides (15). It is quite clear, however, that intravenous administration of the drug has a more pronounced effect.

It should also be noted that maximal stimulation of the adrenal cortex is readily effected also after administration of rather small doses of 18-ACTH. The effect of larger doses is seen largely on the duration of stimulation (fig. 1).

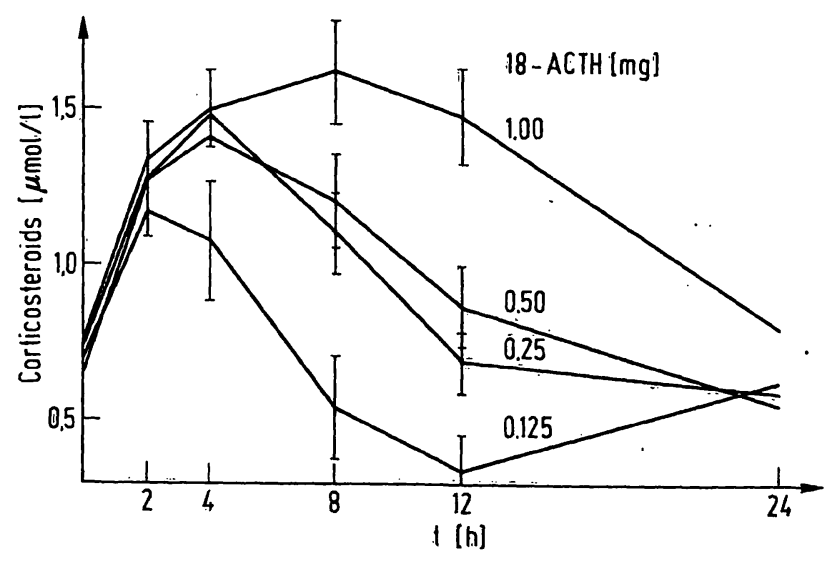

Fig. 1. Plasma corticosteroid levels after intramuscular administration of different doses of 18-ACTH. 
Tab. 1. Plasma corticosteroid levels after administration of 18-ACTH

\begin{tabular}{|c|c|c|c|c|c|c|c|c|c|}
\hline \multirow{2}{*}{$\begin{array}{l}\text { Dose of } \\
\text { 18-ACTH } \\
\text { (mg) }\end{array}$} & \multirow{2}{*}{$\begin{array}{l}\text { Mode of } \\
\text { admini- } \\
\text { stration }\end{array}$} & \multicolumn{8}{|c|}{ Corticosteroid levels $(\mu \mathrm{mol} / \mathrm{l})$ after } \\
\hline & & $\mathbf{O h}$ & $2 \mathrm{~h}$ & $4 \mathrm{~h}$ & $8 \mathrm{~h}$ & $12 \mathrm{~h}$ & $24 \mathrm{~h}$ & $36 \mathrm{~h}$ & $48 \mathrm{~h}$ \\
\hline 0.125 & $\begin{array}{l}\text { s.c. } \\
\text { i.m. } \\
\text { i.v. }\end{array}$ & $\begin{array}{l}0.57 \\
0.18 \\
0.70 \\
0.16 \\
0.80 \\
0.19\end{array}$ & $\begin{array}{l}1.14 \\
0.42 \\
1.17 \\
0.34 \\
1.32 \\
0.25\end{array}$ & $\begin{array}{l}0.92 \\
0.53 \\
1.08 \\
0.43 \\
1.54 \\
0.32\end{array}$ & $\begin{array}{l}0,39 \\
0.55 \\
0.54 \\
0.33 \\
1.30 \\
0.39\end{array}$ & $\begin{array}{l}0.27 \\
0.40 \\
0.34 \\
0.23 \\
0.97 \\
0.35\end{array}$ & $\begin{array}{l}0.60 \\
0.18 \\
0.62 \\
0.17 \\
0.52 \\
0.31\end{array}$ & $\begin{array}{l}0.40 \\
0.24\end{array}$ & $\begin{array}{l}0.70 \\
0.19\end{array}$ \\
\hline 0.25 & $\begin{array}{l}\text { s.c. } \\
\text { i.m. } \\
\text { i.v. }\end{array}$ & $\begin{array}{l}0.57 \\
0.24 \\
0.77 \\
0.17 \\
0.69 \\
0.20\end{array}$ & $\begin{array}{l}1.16 \\
0.47 \\
1.33 \\
0.42 \\
1.38 \\
0.26\end{array}$ & $\begin{array}{l}1.27 \\
0.55 \\
1.48 \\
0.49 \\
1.66 \\
0.37\end{array}$ & $\begin{array}{l}1.03 \\
0.52 \\
1.11 \\
0.37 \\
1.78 \\
0.42\end{array}$ & $\begin{array}{l}0.62 \\
0.37 \\
0.69 \\
0.24 \\
1.67 \\
0.37\end{array}$ & $\begin{array}{l}0.49 \\
0.19 \\
0.58 \\
0.17 \\
0.99 \\
0.30\end{array}$ & $\begin{array}{l}0.42 \\
0.26\end{array}$ & $\begin{array}{l}0.61 \\
0.23\end{array}$ \\
\hline 0.50 & $\begin{array}{l}\text { s.c. } \\
\text { i.m. } \\
\text { i.v. }\end{array}$ & $\begin{array}{l}0.52 \\
0.19 \\
0.72 \\
0.18 \\
0.70 \\
0.22\end{array}$ & $\begin{array}{l}1.07 \\
0.45 \\
1.26 \\
0.35 \\
1.45 \\
0.29\end{array}$ & $\begin{array}{l}1.27 \\
0.48 \\
1.41 \\
0.53 \\
1.69 \\
0.34\end{array}$ & $\begin{array}{l}1.23 \\
0.56 \\
1.20 \\
0.37 \\
1.77 \\
0.43\end{array}$ & $\begin{array}{l}0.91 \\
0.44 \\
0.86 \\
0.22 \\
1.72 \\
0.34\end{array}$ & $\begin{array}{l}0.52 \\
0.20 \\
0.54 \\
0.18 \\
1.26 \\
0.29\end{array}$ & $\begin{array}{l}0.54 \\
0.23\end{array}$ & $\begin{array}{l}0.63 \\
0.25\end{array}$ \\
\hline 1.00 & $\begin{array}{l}\text { s.c. } \\
\text { i.m. } \\
\text { i.v. }\end{array}$ & $\begin{array}{l}0.64 \\
0.19 \\
0.66 \\
0.23 \\
0.70 \\
0.23\end{array}$ & $\begin{array}{l}1.18 \\
0.41 \\
1.26 \\
0.39 \\
1.45 \\
0.32\end{array}$ & $\begin{array}{l}1.40 \\
0.50 \\
1.49 \\
0.46 \\
1.70 \\
0.42\end{array}$ & $\begin{array}{l}1.40 \\
0.52 \\
1.62 \\
0.32 \\
1.94 \\
0.47\end{array}$ & $\begin{array}{l}1.15 \\
0.37 \\
1.47 \\
0.21 \\
2.05 \\
0.40\end{array}$ & $\begin{array}{l}0.54 \\
0.19 \\
0.79 \\
0.17 \\
1.95 \\
0.33\end{array}$ & $\begin{array}{l}1.17 \\
0.27\end{array}$ & $\begin{array}{l}0.77 \\
0.25\end{array}$ \\
\hline
\end{tabular}

Corticosteroid values were estimated by fluorometric analysis ( $f$ ) and by radio-immuno-assay (ria). Each value given is the mean of six independent values. Standard deviations of the means (SEM) are $s_{\bar{x}}=0.16$ (f) and $s_{\bar{x}}=0.04$ (ria).

Tab. 2. Relative activity of different doses of 18-ACTH expressed as surface $\left(\mathrm{cm}^{2}\right)$ under the curves in the graphical presentation of plasma-corticosteroid levels against time after administration. Calculated values from fluorometric and from radio-immuno-assay methods for corticosteroid estimation.

Variation coefficient for fluorimetric assay $10 \%$ and for radioimmunoassay $9 \%$.

\begin{tabular}{lrrrr}
\hline Administration & \multicolumn{5}{c}{ Dose of 18 -ACTH (mg) } \\
& 0.125 & 0.25 & 0.50 & 1.00 \\
& Surface $\left(\mathrm{cm}^{2}\right)$ & & \\
\hline subcutaneous & 128.6 & 187.9 & 214.8 & 252.0 \\
& 90.7 & 92.0 & 94.8 & 87.3 \\
intramuscular & 147.8 & 211.5 & 222.5 & 304.8 \\
& 63.6 & 70.4 & 67.4 & 63.2 \\
intravenous & 240.3 & 341.1 & 370.2 & 443.6 \\
& 78.8 & 86.2 & 79.1 & 92.0 \\
\hline
\end{tabular}

In tables $3 a$ and $3 b$ measured plasma $\mathrm{ACTH}$ values are given. These values are composed of the sum of administered $\beta^{\mathbf{1 - 1 8}}$-corticotrophinamide and endogenous human ACTH. Relatively elevated values are detected very soon after the subcutaneous or intravenous administration of the synthetic drug. In the latter case however the values diminish more rapidly, possibly on account of suppression of endogenous ACTH produc- tion by rapidly increasing plasma cortisol values as a result of the action of the administered 18-ACTH on the adrenal cortex.

\section{Conclusions}

a. After administration of 18-ACTH in doses ranging from $0.125 \mathrm{mg}$ to $1.00 \mathrm{mg}$ there is not much difference in the attained plasma corticosteroid levels. The observed effect of the drug on adrenocortical activity is more persistent after the administration of the larger doses. b. About the same corticotrophic activity is obtained after administration of either $0.25 \mathrm{mg}$ or $0.50 \mathrm{mg}$ of 18-ACTH. It therefore seems unnecessary to use the larger dose.

c. Intravenous administration of the drug has the stronger effect for all doses. However it should be mentioned here that in some cases after the administration of $1.00 \mathrm{mg}$ of $18-\mathrm{ACTH}$ by intravenous injection, significant weight gain (up to $3 \mathrm{~kg}$ ) was observed which might be due to water retention; this lasted for up to four days. In some cases, this same intravenous dose also caused generalized erythema, which developed within a few minutes after the injection and disappeared again within fifteen minutes. As the participants in the trial had not been sensitized before, this erythema can not be considered as a specific allergic reaction. 
Tab. 3a. Total content of corticotrophins in plasma after administration of $0.25 \mathrm{mg}$ of 18-ACTH via different modes of administration:

corticotrophins estimated by radio-immuno-assay, Variation coefficient $16 \%$.

\begin{tabular}{|c|c|c|c|c|c|c|c|c|}
\hline $\begin{array}{l}\text { Mode of } \\
\text { admini- } \\
\text { stration }\end{array}$ & $\begin{array}{l}\text { Tin } \\
0 \\
\text { Tot }\end{array}$ & $\begin{array}{l}\text { after } \\
2 \\
\text { cortic }\end{array}$ & $\begin{array}{c}\mathrm{dmin} \\
4 \\
\mathrm{trop}\end{array}$ & $\begin{array}{l}\text { tration } \\
8 \\
\text { ns }(\mu \mathrm{g} / 1\end{array}$ & $\begin{array}{l}\text { (hours } \\
12 \\
1 \text { ) }\end{array}$ & 24 & 36 & 48 \\
\hline $\begin{array}{l}\text { subcuta- } \\
\text { neous }\end{array}$ & 83 & 175 & 338 & 342 & 195 & 90 & & \\
\hline $\begin{array}{l}\text { intramus- } \\
\text { cular }\end{array}$ & 89 & 174 & 194 & 345 & 269 & 129 & & \\
\hline $\begin{array}{l}\text { intra- } \\
\text { venous }\end{array}$ & 89 & 193 & 366 & 226 & 271 & 125 & 133 & 85 \\
\hline
\end{tabular}

On account of these side effects we do not recommend the use of the drug for intravenous administration. d. The corticosteroid values as estimated by radio-immunoassay are significantly lower than those obtained by fluorometric analysis. This is probably due to greater selectivity of the immunological procedure. The question arises whether it would be advisable to abandon the fluorometric method in investigations as described here. This depends on the problem of the better parameter of adrenocortical activity: plasma cortisol values
Tab. 3b. Total content of corticotrophins in plasma after administration of 18-ACTH.

Variation coefficient $16 \%$.

\begin{tabular}{|c|c|c|c|c|c|c|c|c|c|}
\hline \multirow{2}{*}{$\begin{array}{l}\text { Dose of } \\
18-A C T H \\
(\mathrm{mg})\end{array}$} & \multirow{2}{*}{$\begin{array}{l}\text { Admini- } \\
\text { stration }\end{array}$} & $\begin{array}{l}\text { Tim } \\
0 \\
\text { Tota }\end{array}$ & $\begin{array}{l}\text { ie afte } \\
2 \\
\text { al cort }\end{array}$ & $\begin{array}{c}\text { adn } \\
4 \\
\text { ticotr }\end{array}$ & $\begin{array}{c}\text { minist } \\
8 \\
\text { rophir }\end{array}$ & $\begin{array}{c}\text { tratio } \\
12 \\
\text { n }(\mu \mathrm{g})\end{array}$ & $\begin{array}{l}\text { n (ho } \\
24 \\
\text { /1) }\end{array}$ & $\begin{array}{c}\text { ours) } \\
36\end{array}$ & 48 \\
\hline & & 92 & 163 & 222 & 214 & 163 & 96 & & \\
\hline 0.25 & s.c. & 83 & 175 & 338 & 342 & 195 & 90 & & \\
\hline 0.25 & i.m. & 89 & 174 & 194 & 345 & 269 & 129 & & \\
\hline 0.25 & i.v. & 89 & 193 & 366 & 226 & 271 & 125 & 133 & 85 \\
\hline 1.00 & i.v. & 83 & 374 & 374 & 274 & 220 & 200 & 125 & 108 \\
\hline
\end{tabular}

or total plasma corticosteroid values. For the time being we think the overall fluorometric method should be retained.

e. There is no evident relation between the measured values of total plasma corticotrophins and the corticosteroid values obtained by either method. This might be due to lack of specificity of the corticotrophin estimation where both the administered and the endogenous peptides are measured simultaneously.

\section{References}

1. Buytendijk, H. \& Maesen, F. (1964), Poumon 20, 151-156.

2. Charpin, J., Zafiropoulo, A., Aubert, J., Ohresser, Ph. \& Boutin, Ch. (1964), Presse Méd. Paris 72, 3025-3028.

3. Arnoldsson, H. (1955), Acta Allergol. 8, 369-377.

4. Schwyzer, R. \& Kappeler, H. (1963), Helv. Chim. Acta $46,1550-1572$.

5. Brombacher, P. J., Buytendijk, H. \& Maesen, F. (1969), this j. 7, 291-292.

6. Hoffman, K. (1962), Ann. Rev. Bioch. 31, 213-246.

7. Buytendijk, H., Brombacher, P. \& Maesen, F. (1968), Acta Tubercol Pneumol. Belg., 59, 471-478.

8. Brombacher, P., Buytendijk, H. \& Maesen, F. (1969), Acta Tubercol. Pneumol. Belg. 60, 864-877.

9. Riniker, B. \& Rittel, W. (1970), Helv. Chim. Acta 53, 513519.

10. Walser, A. \& Müller, Th. (1968), Helv. Med. Acta, suppl. $48,125$.

11. Mattingly, D. (1962), J. Clin. Pathol. 15, 374-379.

12. Fiorelli, G., Piolanti, P., Forti, G. \& Serio, M., Clin. Chim. Acta 37, 179-187.

13. Desaulles, P., Riniker, B. \& Rittel, W. (1969), Proc. Int. Symp. on Proteins and Polypeptide Hormones, Liège 1968, Ed. M. Margolies, Exc. Medica Amsterdam 1969.

14. Walser, A., Keller, R. \& Herzog, H. (1969), Schweiz, Med. Wochenschr. 99, 1726-1728.

15. Brombacher, P., Buytendijk, H. \& Maesen, F., Wenckebachbundel, P. 159-166, Heerlen 1968.

16. Landon, J. \& Greenwood, F. C. (1968), Lancet $I, 273-276$.

17. Ratcliffe, J. G. \& Edwards, C. R. W. (1971). in Radioimmunoassay Methods (Kirkham-Hunter eds.), p 505-512, Edinburgh, Churchill Livingstone.
Drs. P. J. Brombacher, Department of Clinical Chemistry, De-Wever-Ziekenhuis, Heerlen. (L)

The Netherlands. 